\title{
High-resolution projections of surface water availability for Tasmania, Australia
}

\author{
J. C. Bennett ${ }^{1,2,3,{ }^{*} \text {, F. L. N. Ling }}$, D. A. Post ${ }^{4}$, M. R. Grose ${ }^{2}$, S. P. Corney ${ }^{2}$, B. Graham ${ }^{5}$, G. K. Holz ${ }^{2}$, J. J. Katzfey ${ }^{6}$, \\ and N. L. Bindoff ${ }^{1,2,6}$ \\ ${ }^{1}$ Institute for Marine and Antarctic Studies (IMAS), University of Tasmania, Sandy Bay, Tasmania, Australia \\ ${ }^{2}$ Antarctic Climate and Ecosystems Cooperative Research Centre (ACE CRC), University of Tasmania, Sandy Bay, \\ Tasmania, Australia \\ ${ }^{3}$ Entura, Cambridge Park, Tasmania, Australia \\ ${ }^{4}$ Commonwealth Scientific and Industrial Research Organisation (CSIRO) Land and Water (CLW), Black Mountain, \\ Australian Capital Territory, Australia \\ ${ }^{5}$ Department of Primary Industries, Parks, Water and Environment, New Town, Tasmania, Australia \\ ${ }^{6}$ Centre for Australian Weather and Climate Research, CSIRO Marine and Atmospheric Research (CMAR), Aspendale, \\ Victoria, Australia \\ * now at: CLW, Highett, Victoria, Australia
}

Correspondence to: J. C. Bennett (james.bennett@csiro.au)

Received: 16 December 2011 - Published in Hydrol. Earth Syst. Sci. Discuss.: 8 February 2012

Revised: 15 April 2012 - Accepted: 16 April 2012 - Published: 7 May 2012

\begin{abstract}
Changes to streamflows caused by climate change may have major impacts on the management of water for hydro-electricity generation and agriculture in Tasmania, Australia. We describe changes to Tasmanian surface water availability from 1961-1990 to 2070-2099 using high-resolution simulations. Six fine-scale $\left(\sim 10 \mathrm{~km}^{2}\right)$ simulations of daily rainfall and potential evapotranspiration are generated with the CSIRO Conformal Cubic Atmospheric Model (CCAM), a variable-resolution regional climate model (RCM). These variables are bias-corrected with quantile mapping and used as direct inputs to the hydrological models AWBM, IHACRES, Sacramento, SIMHYD and SMAR-G to project streamflows.

The performance of the hydrological models is assessed against 86 streamflow gauges across Tasmania. The SIMHYD model is the least biased (median bias $=-3 \%$ ) while IHACRES has the largest bias (median bias $=-22 \%$ ). We find the hydrological models that best simulate observed streamflows produce similar streamflow projections.

There is much greater variation in projections between RCM simulations than between hydrological models. Marked decreases of up to $30 \%$ are projected for annual runoff in central Tasmania, while runoff is generally
\end{abstract}

projected to increase in the east. Daily streamflow variability is projected to increase for most of Tasmania, consistent with increases in rainfall intensity. Inter-annual variability of streamflows is projected to increase across most of Tasmania.

This is the first major Australian study to use highresolution bias-corrected rainfall and potential evapotranspiration projections as direct inputs to hydrological models. Our study shows that these simulations are capable of producing realistic streamflows, allowing for increased confidence in assessing future changes to surface water variability.

\section{Introduction}

Human-induced climate change has been shown to contribute to changes in the spatial distribution of precipitation in the 20th century (Zhang et al., 2007). In a warmer future world, understanding the local and regional implications of changes in the hydrological cycle is critical to planning for water security (Oki and Kanae, 2006). Dynamical regional climate models (RCMs) have been used to assess climate change impacts on spatial distributions of rainfall (Kilsby, 2007), seasonal changes to rainfall (Kendon et al., 2010), and changes 
to rainfall intensity (Berg et al., 2009) and frequency (Mailhot et al., 2007) at spatial scales relevant to water managers.

To assess how complex rainfall changes affect surface water availability, RCM outputs are often coupled to hydrological models. RCMs and hydrological models can be coupled indirectly by adjusting historical observations to resemble the future climate (Chiew et al., 2009), or directly by using timeseries generated by RCMs in hydrological models (Wood et al., 2004; Kilsby et al., 2007; Akhtar et al., 2009). Fowler and Kilsby (2007) point out that indirect coupling methods often do not explicitly account for changes to rainfall variability or to changes in the sequences of wet and dry days, even though these are likely to have significant impacts on streamflow.

Coupling RCMs directly to hydrological models has the advantage that the complex rainfall changes projected by RCMs, including changes to seasonal rainfall, maximum daily precipitation, and number of rain days, will be reflected in projections of streamflow. This allows more meaningful assessment of climate change impacts on streamflow volumes and variability.

The challenge in coupling RCMs directly to hydrological models is that RCM outputs are usually too biased to allow hydrological models to produce realistic streamflows (Graham et al., 2007). Quantile mapping is a bias-correction technique shown to be highly effective at removing biases across the entire cumulative frequency distribution of a given variable (Ines and Hansen, 2006; Piani et al., 2010a). Quantile mapping has been successfully used to couple RCMs to hydrological models in several northern hemisphere studies (Wood et al., 2004; Fowler and Kilsby, 2007; Boé et al., 2007; Akhtar et al., 2009), but has not been used for major regional hydroclimatological studies in Australia, where indirect coupling methods based on pattern scaling and simple perturbation of historical observations have been more popular (Chiew et al., 2009; Petheram et al., 2009; Charles et al., 2010; Post et al., 2012).

The spatial distribution of Tasmanian rainfall is very poorly replicated by global climate models (GCMs), making Tasmania an ideal candidate for fine-scale modelling. Tasmania has been the subject of a major hydroclimatological study by Post et al. (2012) that reviewed future availability of surface water in Tasmania to 2030. Post et al. (2012) used pattern scaling (Mitchell, 2003) of GCMs and a series of hydrological models to better replicate spatial variation in Tasmanian runoff. Post et al.'s (2012) median future scenario projected decreased mean annual runoff in Tasmania's central highlands and north-eastern highlands of up to $30 \%$ by 2030 , with little change elsewhere. No region was projected to experience increased runoff under the median scenario by 2030 . Post et al. (2012) note that there are plans to develop new irrigation infrastructure in Tasmania in light of declining agricultural yields in the Murray Darling Basin and south-west Western Australia. Longer-term high-resolution projections of surface water availability are needed for informed water management and planning in Tasmania for the 21 st century.

This paper's primary aim is to quantify seasonal and spatial changes in Tasmanian streamflows by 2100 using highresolution RCM simulations. To better understand future changes in streamflow variability, we project streamflows using bias-corrected RCM projections as direct inputs to hydrological models. Ours is the first Australian study to use this method to produce basin-scale surface water projections, and accordingly we aim to demonstrate that our method credibly replicates historical streamflows.

Finally, this paper aims to understand whether uncertainty in the streamflow projections comes more from the RCM simulations than from the hydrological modelling. The practice of using ensembles of climate models to describe uncertainty in projections is well established. Using ensembles of hydrological models to quantify uncertainty in projections is less common, even though uncertainties in hydrological modelling may contribute significantly to uncertainties in climate change impact studies (Bastola et al., 2011). To find if the RCM simulations are a greater source of uncertainty than the hydrological models, we couple an ensemble of RCM simulations to an ensemble of hydrological models.

\section{Study area: Tasmania}

Tasmania is Australia's smallest $\left(\sim 70000 \mathrm{~km}^{2}\right)$ and most southerly state, in addition to being Australia's only island state. Tasmania is mountainous, with mountain ranges in the north-east (Ben Lomond Plateau), centre (central highlands), west and south all exceeding $1000 \mathrm{~m}$ in elevation. Tasmania lies in the path of the "Roaring Forties" winds (Fig. 1), and the prevailing westerly weather combines with the mountains to make western Tasmania one of the wettest places in Australia. Mean annual rainfalls exceed $2000 \mathrm{~mm}$ for much of the west and rise to more than $4000 \mathrm{~mm}$ on some mountain peaks (Fig. 2a). Rainfall in the west is highest in the austral winter (June-July-August, JJA) and lowest in summer (DecemberJanuary-February, DJF). Snowfalls are common on Tasmanian mountains, however snow typically melts within a few weeks and seasonal snowmelt is not an important component of Tasmanian streamflows. The central, western and southwestern mountains are of high conservation value and much of this unpopulated region is listed as a UNESCO world heritage area.

Tasmanian mean annual rainfall follows a sharp gradient from west to east, with the central midlands and eastern lowlands averaging less than $600 \mathrm{~mm}$ (Fig. 2a). In contrast to the winter-dominant rainfall in the west and north-west, rainfall in the east does not show a strong seasonal cycle. Low pressure systems off the east coast cause occasional highintensity rain storms over eastern Tasmania. Despite the low and less reliable rainfall, agriculture is an important industry in the lowlands of the east. 


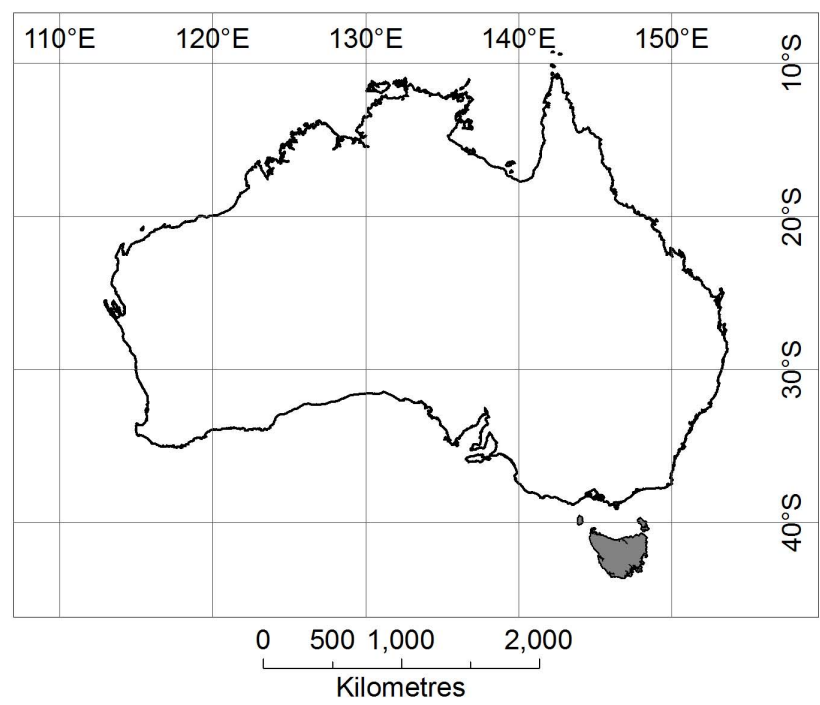

Fig. 1. Tasmania's location (shaded) in relation to the Australian continent.

Mean annual areal potential evapotranspiration (APET) is highest $(>1100 \mathrm{~mm})$ in the central north of Tasmania and declines to $<850 \mathrm{~mm}$ in the south and west (Fig. 2b). These patterns of APET and rainfall combine to give Tasmania a very steep west-to-east gradient in mean annual runoff, from $>3000 \mathrm{~mm}$ on the western mountains to $<100 \mathrm{~mm}$ in some eastern areas (Fig. 2c). An exception to this west-to-east gradient is the small, mountainous Ben Lomond plateau in the north-east of Tasmania, where high mean annual runoff $(>1200 \mathrm{~mm})$ occurs.

\section{Data and methods}

\subsection{Regional climate modelling}

Regional climate simulations are produced for 1961-2100 by downscaling GCMs with the CSIRO Conformal Cubic Atmospheric Model (CCAM) (Corney et al., 2010), a variableresolution global atmospheric model (McGregor and Dix, 2008). Variable-resolution global atmospheric models have been shown to simulate rainfall and related processes realistically at a range of scales and locations (Berbery and FoxRabinovitz, 2003; Boé and Terray, 2007; Zou et al., 2010). Although a global model, CCAM is designed to increase resolution over small regions, and we refer to the CCAM simulations in this study as RCM simulations. CCAM has no lateral boundaries and accordingly does not suffer from the problems associated with lateral boundaries in limited area RCMs (Fox-Rabinovitz et al., 2008). CCAM has been used for regional climate studies in Australia (Charles et al., 2007; Chiew et al., 2010; Post et al., 2012) and internationally (Engelbrecht et al., 2009; Lal et al., 2008).
For climate change studies, CCAM can be configured to be forced only with sea surface temperatures (SSTs) and sea ice, together with radiative forcings, from which CCAM simulates the atmosphere (Engelbrecht et al., 2009). For this study, we force CCAM with SSTs and sea ice from six GCMs from phase 3 of the coupled model intercomparison project (CMIP3) (Meehl et al., 2007) run under the A2 emissions scenario (Nakićenović and Swart, 2000): CSIROMk3.5, ECHAM5/MPI-OM, GFDL-CM2.0, GFDL-CM2.1, MIROC3.2(medres) and UKMO-HadCM3. Radiative forcings for the CCAM simulations, including atmospheric concentrations of greenhouse gases, are taken from the A2 scenario to correspond to the GCM forcings. For convenience, each RCM simulation will be referred to by the GCM used to force it.

Before downscaling, monthly biases in the GCM SSTs are removed using a simple additive bias-correction (Katzfey et al., 2009) to Reynolds (1988) SSTs. Correcting GCM SST biases improved the simulation of seasonal precipitation patterns (Ashfaq et al., 2010) and precipitable water (Held and Soden, 2006) in GCM experiments, and improved rainfall simulations by CCAM in experiments over tropical regions (Nguyen et al., 2011). GCM SST biases can exceed $\pm 3{ }^{\circ} \mathrm{C}$ for the GCMs used in this study (Randall et al., 2007), with the largest biases occurring at high latitudes and near the west coasts of South America and Africa. We found the bias-correction removed SST biases very effectively in splitsample cross-validation tests (not shown). In almost all regions cross-validated biases were less than $\pm 0.5^{\circ} \mathrm{C}$ for all GCMs. No cross-validated SST biases were greater than $\pm 1^{\circ} \mathrm{C}$. This suggests that the SST bias-correction is likely to be reliable for the period 2010-2100.

Each GCM is downscaled in two stages: stage two is nested inside stage one. The two stages are necessary to allow CCAM to resolve synoptic processes everywhere on earth for the $10 \mathrm{~km}^{2}$ regional simulations (Thatcher and McGregor, 2011). Stage one uses only the bias-corrected SSTs and sea ice from GCMs, together with radiative forcings, to produce atmospheric simulations with a horizontal resolution of $\sim 50 \mathrm{~km}^{2}\left(0.5^{\circ}\right)$ over Australia. Stage two uses the same GCM SSTs and sea ice forcings (and radiative forcings) as stage one, and is also forced by spectral nudging (Thatcher and McGregor, 2009) of atmospheric variables from the stage one simulations. Stage two produces an approximate horizontal resolution of $\sim 10 \mathrm{~km}^{2}\left(0.1^{\circ}\right)$ over Tasmania. Because stage two is nested inside stage one, CCAM is forced only by SSTs and sea ice from GCMs to produce high resolution simulations over Tasmania.

\subsection{Quantile mapping}

Two inputs are required for the hydrological models: daily rainfall and daily APET. We use quantile mapping to align daily rainfalls and APET to $10 \mathrm{~km}^{2}$ gridded observations aggregated from the $\sim 5 \mathrm{~km}^{2}\left(0.05^{\circ}\right)$ SILO dataset (Jeffrey et 

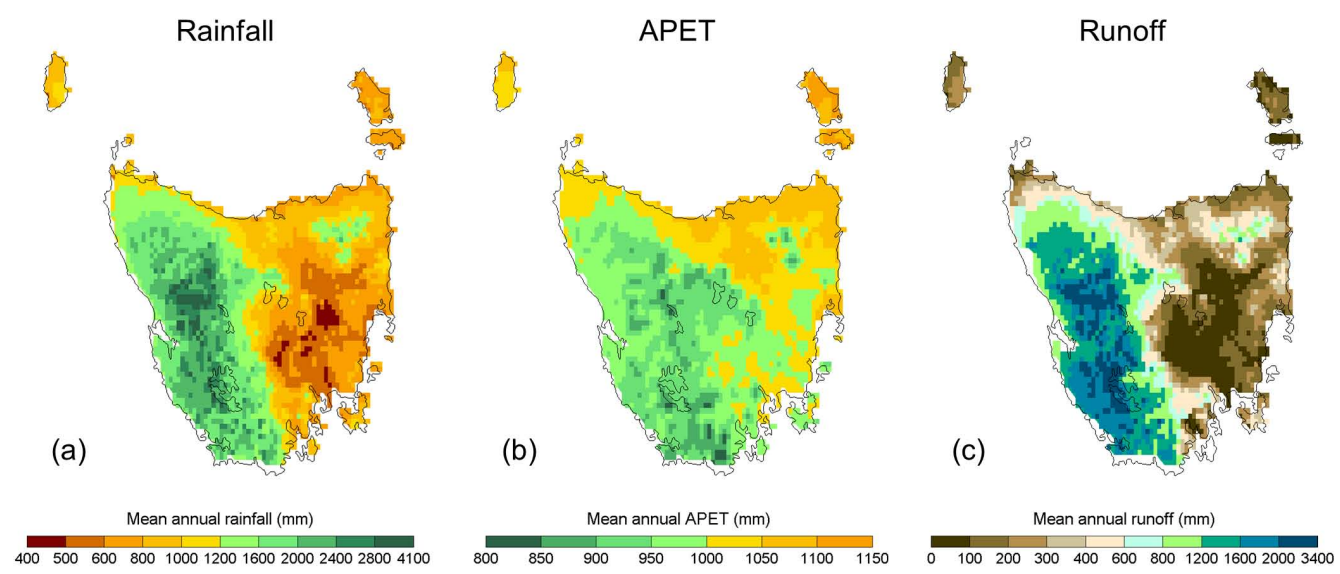

Fig. 2. Tasmanian historical climate (1961-2007) derived from the SILO climate dataset (Jeffrey et al., 2001). (a) Mean annual rainfall. (b) Mean annual Morton's (1983) wet APET calculated from SILO temperature, solar radiation and vapour pressure. (c) Mean annual runoff generated with the SIMHYD model using SILO variables.

al., 2001). Rainfall is a direct output from the SILO dataset, while APET is calculated from base variables (vapour pressure, temperature and solar radiation) according to Morton's (1983) method for wet environments.

We calculate "quantile mapping factors" independently at each grid cell for each RCM simulation:

$F_{i}=\left\{\begin{array}{l}\frac{P_{i}(\mathrm{Obs})}{P_{i}(\mathrm{RCM})}: P_{i}(\mathrm{RCM})>0 \\ 1: P_{i}(\mathrm{RCM})=0\end{array}\right.$ and $i=\{0.5,1.5, \ldots, 98.5,99.5\}$ (1)

where $F_{i}$ is the quantile mapping factor at the $i$ th percentile, and $P_{i}(\mathrm{Obs})$ and $P_{i}(\mathrm{RCM})$ are the $i$ th percentiles of observation and RCM outputs, respectively. This is similar to the method of $\mathrm{Li}$ et al. (2010) in that we independently correct moments of the cumulative frequency distribution, however, we calculate corrections from empirical cumulative frequency distributions. When RCM outputs are zero for Eq. (1), the quantile mapping factor is set to $1\left(F_{i}=1\right)$. Quantile mapping factors are calculated for each percentile from 0.5 to 99.5 (0.5th, 1.5th, ..., 98.5th, 99.5th). Percentiles are calculated from all data, including days of zero rain. Quantile mapping factors are calculated independently at each grid cell for the seasons DJF, March-April-May (MAM), JJA, and September-October-November (SON) for the training period 1961-2007.

We force any rain day with rainfall of less than $0.2 \mathrm{~mm}$ to zero in both observed and modelled rain time series. The threshold of $0.2 \mathrm{~mm}$ is chosen because it is the lower resolution limit of the Bureau of Meteorology rain gauges that are the basis of the SILO dataset.

Before the quantile mapping is implemented, we detrend each season in the uncorrected simulation (1961-2100) by subtracting a 30-yr moving average to remove any long-term changes in rainfall regimes. Each day from this detrended series is consigned to a percentile "bin" between integer percentiles (i.e. percentile bins of $0-1,1-2, \ldots, 98-99,99-100$ ), and assigned a rank that accords to the bin. These ranks are then transferred to the original (undetrended) simulation. Bias-corrected RCM outputs are calculated for each day for the entire simulation by

$$
\begin{aligned}
& \operatorname{RCM}_{b}^{\prime}=F_{i} \cdot \mathrm{RCM}_{b}: i=\{0.5,1.5, \ldots, 98.5,99.5\} \\
& \text { and }\left\{\begin{array}{l}
\{i-0.5 \leq b>i+0.5\}: b<99.5 \\
\{i-0.5 \leq b \geq i+0.5\}: b=99.5
\end{array}\right.
\end{aligned}
$$

where $\mathrm{RCM}_{b}$ and $\mathrm{RCM}_{b}^{\prime}$ are the uncorrected and corrected simulations, respectively, falling in percentile bin $b$. The other terms are as described for Eq. (1). Equation (2) applies the quantile mapping factors calculated at the 0.5 th percentile to the $0-1$ percentile bin, the factor for the 1.5 th percentile is matched to the 1-2 percentile bin, and so on up to the factor for the 99.5th percentile, which is applied to the 99-100 percentile bin.

Finally, bias-corrected RCM outputs are regridded from the $10 \mathrm{~km}^{2}$ CCAM grid to the $5 \mathrm{~km}^{2}$ grid compatible with the hydrological models.

\subsubsection{Split-sample cross-validation of quantile mapping}

When bias-corrections are applied to future projections, they are often implicitly assumed to be consistent through time (Ines and Hansen, 2006; Wood et al., 2004). However, there is some evidence that bias-corrections can vary with the choice of training period (Piani et al., 2010b; Li et al., 2010). We test this assumption using split-sample cross-validation for quantile mapping of rainfall. We carry out two sets of cross-validation:

1. We train the quantile mapping for the period 1962-1984 and validate against the period 1985-2007. 
2. To minimise the effects of longer-term (decadal or greater) oscillations or trends in either the observed or simulated rainfalls, we train the quantile mapping on odd years for 1962-2007 (1963, 1965, .., 2005, 2007) and validate against even years for 1962-2007 (1962, $1964, \ldots, 2004,2006)$.

\subsection{Hydrological modelling}

We use the five hydrological models calibrated by Viney et al. (2009b): AWBM (Boughton, 2004), IHACRES (Post and Jakeman, 1999), Sacramento (Burnash et al., 1973), SIMHYD (Chiew et al., 2002) with Muskingum routing (Tan et al., 2005), and SMAR-G (Goswami et al., 2002). The hydrological models are simple conceptual models that use a variety of algorithms to partition available water into baseflows and quickflows, which are then combined to represent observed hydrographs. IHACRES is distinguished from the other models by (i) employing a rainfall scaling parameter and (ii) by characterising streamflow using a unithydrograph. Viney et al. (2009b) used a log-bias objective function (Viney et al., 2009a) to automate the calibration of the five hydrological models to 90 streamflow records for 1975-2007 for catchments around Tasmania. The stream records Viney et al. (2009b) chose were from catchments that had negligible human influence on streamflows. For four catchments, streamflow records were augmented with estimates of irrigation extractions to simulate natural streamflows. The hydrological models produce runoff timeseries at a daily time step distributed on a $\sim 5 \mathrm{~km}^{2}\left(0.05^{\circ}\right)$ grid covering all of Tasmania. To achieve Tasmania-wide coverage with the five hydrological models, Viney et al. (2009b) assigned model parameters to ungauged catchments from their nearest gauged neighbour.

We aggregate runoff to eight river catchments (Fig. 3). Operation of storages, diversions and water extractions in these catchments are based on practices current at 31 December 2007 (Bennett et al., 2010). The eight rivers are chosen as they represent different climatic regions of Tasmania, and all have $>20$-yr, high-quality streamflow records.

Descriptions of streamflow changes in a further 70 Tasmanian rivers, 12 large irrigation storages and the Tasmanian hydro-electric system are given by Bennett et al. (2010).

Changes are described between a baseline period, 19611990, and a future period, 2070-2099.

\section{Results}

\subsection{Cross-validation of quantile mapping}

Figure 4 shows cross-validation biases for mean annual rainfall for the GFDL-CM2.0 simulation. Rainfall biases of the GDFL-CM2.0 simulation shown in Fig. 4 are very similar for the other RCM simulations (not shown). When the quantile mapping is trained on odd years $(1963, \ldots, 2007)$,

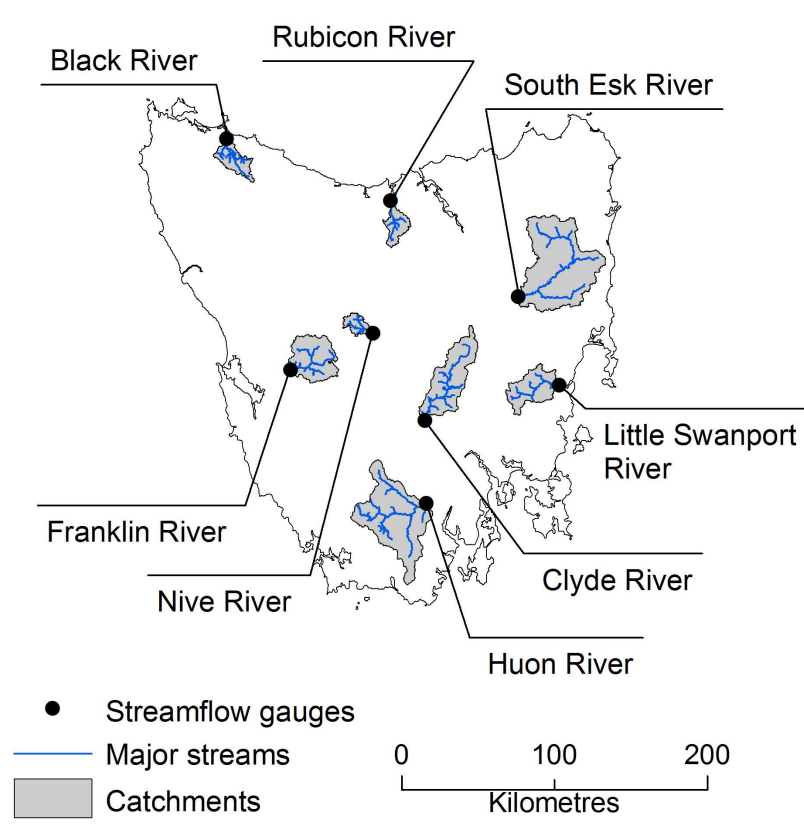

Fig. 3. Catchments reported by this study.

cross-validation biases are less than $\pm 10 \%$ almost everywhere (Fig. 4a). Cross-validation biases are much smaller than biases of uncorrected RCM rainfalls (Fig. 4c). Biases of uncorrected RCM rainfalls are larger than $\pm 30 \%$ for much of Tasmania, and exceed $150 \%$ in some cells. The relatively small cross-validation biases suggest that the quantile mapping is effective outside the training period. Accordingly, the quantile mapping is likely to be reliable for the period 2010-2100. A longer training period (e.g. 30+yr) may have produced even smaller cross-validation biases. We had $47 \mathrm{yr}$ of synchronous simulations and observations, which allowed $23 \mathrm{yr}$ to train the quantile mapping for the cross-validation tests (assuming an equally long validation period). $23 \mathrm{yr}$ may be an insufficiently long period to sample the natural variance in rainfall.

When the quantile mapping is trained on 1962-1984 (Fig. 4b), cross-validation biases are larger $( \pm 10 \%$ to $\pm 25 \%$ ), and occur over larger areas than when the quantile mapping is trained on odd years $(1963, \ldots, 2007)$ (Fig. 4a). This discrepancy in performance is caused by changes in Tasmanian rainfall between 1962-1984 and 1985-2007. The period 1962-1984 experienced higher rainfalls over much of Tasmania than 1985-2007, particularly in eastern Tasmania. RCM simulations are not synchronised with observations, and the change in observed rainfall from 1962-1984 to 19852007 is not present in the RCM simulations. When the quantile mapping is trained to match the higher rainfalls of 1962 1984 , it consequently overestimates rainfall during the drier period 1985-2007 (the exception to this pattern is over the south-western mountains, which experienced very wet years in 1994 and 1996; here the bias-correction underestimates 
Cross-validated rainfall biases $1962,1964, \ldots, 2004,2006$

(a)

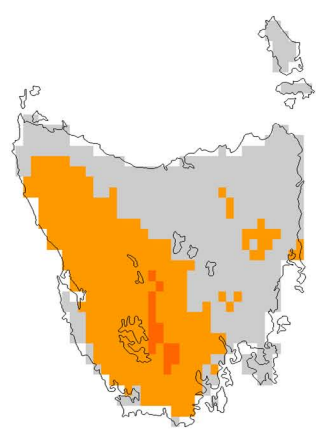

Cross-validated rainfall biases 1985-2007

(b)

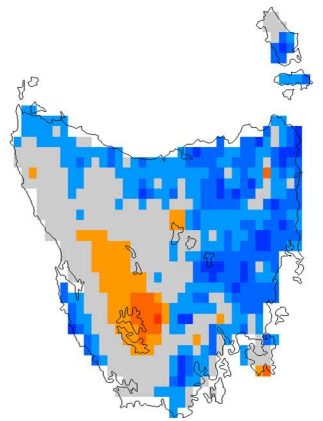

Biases of uncorrected RCM rainfalls 1961-1990

(c)

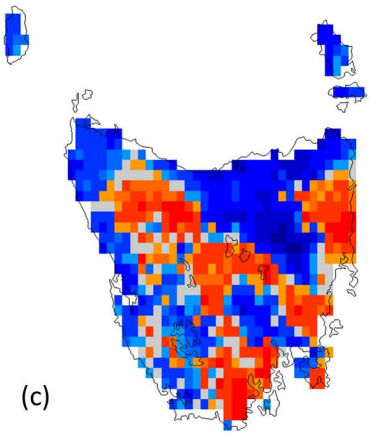

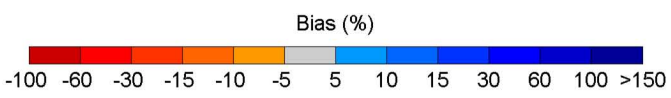

Fig. 4. Effects of changing the training period on quantile mapping performance. Plots show biases in mean annual rainfall for the $10 \mathrm{~km}^{2}$ GFDL-CM2.0 simulation. (a) Biases of bias-corrected RCM rainfall where quantile mapping is trained with the period 1962-1984; biases shown are calculated for 1985-2007. (b) Biases of bias-corrected RCM rainfall where quantile mapping is trained with odd years occurring in the period 1962-2007 (1963, 1965, . ., 2005, 2007); biases shown are calculated for even years occurring during the period 1962-2007 (1962, 1964, .., 2004, 2006). (c) Biases of uncorrected RCM rainfalls for 1961-1990. Rainfall biases for the other five RCM simulations are very similar to the GFDL-CM2.0 simulation illustrated in this figure.

rainfalls in the validation period). These long-term changes in Tasmanian rainfall do not have the same effect on the quantile mapping when it is trained on odd years over a period that includes both wet and dry periods, resulting in lower cross-validation biases (Fig. 4a). This illustrates the importance of sampling long periods to generate temporally stable cumulative frequency distributions for quantile mapping.

\subsection{Performance of hydrological modelling}

\subsubsection{Hydrological model performance under a changing climate}

Performance of a hydrological model may not remain consistent under a changing climate (Merz et al., 2011). Vaze et al. (2010) found that performance of IHACRES, Sacramento, SIMHYD and SMAR-G declined sharply in periods where mean annual rainfall was more than $15 \%$ lower or more than $20 \%$ greater than mean annual rainfall in the calibration period. Simulated mean annual rainfalls for both 1961-1990 and 2070-2099 differed from SILO mean annual rainfall for 1975-2007 (the hydrological model calibration period) by between $-15 \%$ and $+20 \%$ for most of Tasmania for all six RCM simulations (Bennett et al., 2010). This suggests that the hydrological models should perform adequately during the baseline (1961-1990) and future (2070-2099) periods.

\subsubsection{Comparisons of biases of hydrological models}

Performance of hydrological models forced with RCM inputs (RCM-runoff) is assessed at 86 streamflow gauges for all data available for 1961-2007. The 86 catchments range in size from $8 \mathrm{~km}^{2}$ to $>2000 \mathrm{~km}^{2}$, and give good coverage of Tasmania (Fig. 5). Performance is assessed by calculating biases of RCM-runoff against observed streamflows. To isolate the effects of the RCM inputs on hydrological model performance, biases are also calculated for RCM-runoff against streamflows modelled with hydrological models forced by SILO (SILO-runoff). Biases are calculated as:

bias $=\frac{\sum_{t=1}^{T} Q_{\mathrm{m}}-\sum_{t=1}^{T} Q_{\mathrm{o}}}{\sum_{t=1}^{T} Q_{\mathrm{o}}} \times \%$

where $Q_{\mathrm{m}}$ is streamflow modelled with RCM-runoff and $Q_{\mathrm{o}}$ is either observed streamflow or streamflow modelled with SILO-runoff.

Figure 6 shows biases of mean annual streamflows, biases of low streamflows (exceedance probability of $95 \%, Q_{95}$ ) and biases of high streamflows (exceedance probability of $\left.5 \%, Q_{5}\right)$ at 86 sites. Biases vary much more between hydrological models than between RCM simulations (Fig. 6). Low variation between RCM simulations is caused in part by the bias-correction of GCM SSTs before downscaling. Low variation between RCM simulations is also consistent with the use of a single RCM for all the simulations. Because the performance of hydrological models tends not to vary greatly between RCM simulations, we focus on describing hydrological model biases for the mean of the six RCM simulations from here on.

Flows modelled with AWBM, SIMHYD and SMAR-G show similar characteristics to observed mean annual and $Q_{5}$ streamflows for 1961-2007 (Fig. 6, Table 1). AWBM, SIMHYD and SMAR-G replicate observed streamflows 


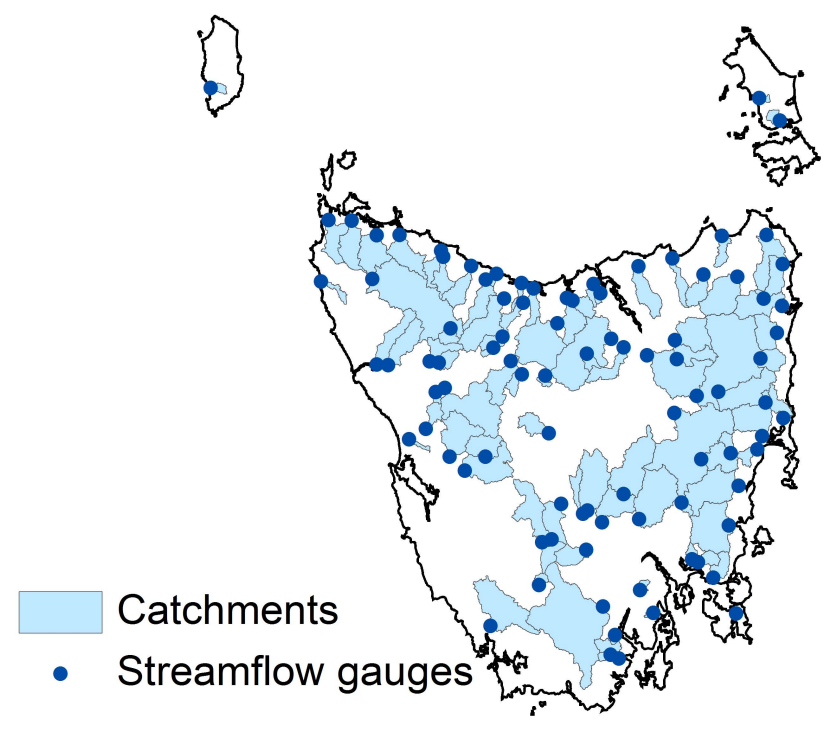

Fig. 5. Catchments and streamflow gauges used to validate hydrological model performance.

well, with biases smaller than $\pm 10 \%$ for more than $40 \%$ of catchments and biases smaller than $\pm 25 \%$ for more than $85 \%$ of catchments. SIMHYD has the smallest median biases (median bias for mean annual streamflows $=-3.2 \%$ ) and smallest interquartile ranges of biases of any hydrological model for annual and seasonal streamflows (Table 1). AWBM, SIMHYD and SMAR-G show a tendency to underpredict observed annual streamflows (underpredicted in $>60 \%$ of catchments) and a stronger tendency to underpredict observed $Q_{5}$ streamflows (underpredicted in $>80 \%$ of catchments). IHACRES is least like observed streamflows (median bias for mean annual streamflows $=-22.3 \%$ ), and Sacramento biases are second largest after IHACRES. IHACRES shows a very strong tendency to underpredict observed mean and $Q_{5}$ streamflows (Fig. 6), and has the largest median biases and largest interquartile ranges of biases against observed annual and seasonal streamflows (Table 1).

RCM-runoff biases are generally smaller against SILOrunoff than against observations for mean streamflows and $Q_{5}$ streamflows (Fig. 6). This is expected as biases calculated against observations add errors in the RCM inputs to errors inherent in the hydrological models, while biases calculated against SILO-runoff reflect differences only between the RCM inputs and SILO variables. In general, RCM-runoff tends to underpredict SILO-runoff. The biascorrection aligns frequency distributions of modelled and observed rainfalls, however it does not account for spatial correlations of rainstorms (how daily rainfalls in all grid cells in a catchment behave together) nor for temporal correlations of rainfall (how rainfalls behave in a multi-day rainstorm). The bias-corrected RCM rainfalls tend to overestimate large daily rainstorms over large areas (Bennett et al., 2011). Underestimation of streamflows is therefore most probably caused by

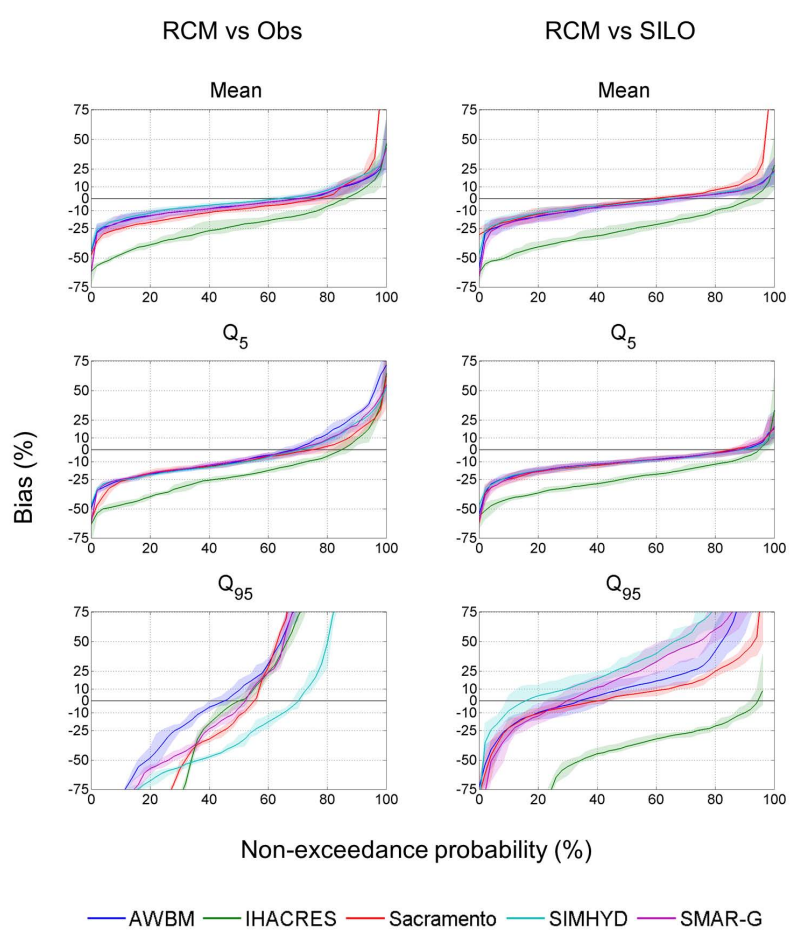

Fig. 6. Non-exceedance probabilities of streamflow biases from the hydrological models forced with the RCM at 86 streamflow gauges for 1961-2007. Left column shows biases calculated against observed streamflows, right column shows biases calculated against streamflows simulated with the hydrological models forced by SILO variables. Biases are shown for mean streamflows (top row), high $\left(Q_{5}\right)$ streamflows (middle row) and low $\left(Q_{95}\right)$ streamflows (bottom row). Lines show mean biases from the six RCM simulations, shaded confidence intervals show the range of biases from the six simulations. For left panels positive biases mean that RCMforced runoff overestimates observations, and for right panels positive biases mean that RCM-forced runoff overestimates SILOforced runoff.

inadequate replication of the temporal characteristics of rainstorms by the bias-corrected RCM inputs.

All RCM-runoff simulations tend not to replicate $Q_{95}$ streamflows as well as higher streamflows (Table 1, Fig. 6). Figure 6 shows that low streamflows generated from SILOrunoff do not replicate observations well. That is, many of the deficiencies in low streamflows emanate from the hydrological models as calibrated for our study, rather than from the bias-corrected RCM inputs. Nonetheless, the biascorrected RCM inputs also contribute to poor performance of low flows. Low flow performance could have been improved by changing the objective function used to calibrate the hydrological models or using different hydrological models (Staudinger et al., 2011), however, this may have reduced performance at mean and high flows. 
Table 1. Summary of biases of hydrological models forced by CCAM calculated at 86 streamflow gauges from the average of the six RCM simulations.

\begin{tabular}{|c|c|c|c|c|c|c|}
\hline & & AWBM & IHACRES & Sacramento & SIMHYD & SMAR-G \\
\hline \multirow[b]{2}{*}{$\begin{array}{l}\text { Mean annual } \\
\text { streamflow }\end{array}$} & Median catchment bias (\%) & -5.2 & -22.6 & -9.1 & -3.2 & -5.8 \\
\hline & $\begin{array}{l}\text { Interquartile range of biases } \\
\text { at all catchments }(\%)\end{array}$ & 14.9 & 20.5 & 16.1 & 11.6 & 14.1 \\
\hline Mean & Median catchment bias (\%) & -7.8 & -15.6 & -25.5 & -6.7 & -12.9 \\
\hline $\begin{array}{l}\text { Nov-Apr } \\
\text { streamflow }\end{array}$ & $\begin{array}{l}\text { Interquartile range of biases } \\
\text { at all catchments }(\%)\end{array}$ & 22.1 & 25.1 & 35.1 & 25.4 & 23.2 \\
\hline Mean & Median catchment bias (\%) & -3.9 & -25.6 & -3.9 & -2.0 & -3.8 \\
\hline $\begin{array}{l}\text { May-Oct } \\
\text { streamflow }\end{array}$ & $\begin{array}{l}\text { Interquartile range of biases (\%) } \\
\text { at all catchments }\end{array}$ & 13.9 & 24.9 & 15.1 & 14.5 & 15.1 \\
\hline \multirow[b]{2}{*}{$\begin{array}{l}Q_{95} \\
\text { streamflows }\end{array}$} & Median catchment bias (\%) & 5.5 & -1.6 & -11.2 & -35.3 & -3.9 \\
\hline & $\begin{array}{l}\text { Interquartile range of biases } \\
\text { at all catchments }(\%)\end{array}$ & 173.3 & 184.9 & 448.8 & 79.7 & 160.9 \\
\hline \multirow{2}{*}{$\begin{array}{l}Q_{5} \\
\text { streamflows }\end{array}$} & Median bias (\%) & -9.8 & -23.4 & -11.4 & -11.5 & -8.8 \\
\hline & $\begin{array}{l}\text { Interquartile range of biases } \\
\text { for all catchments }(\%)\end{array}$ & 26.3 & 26.8 & 17.8 & 20.6 & 23.2 \\
\hline
\end{tabular}
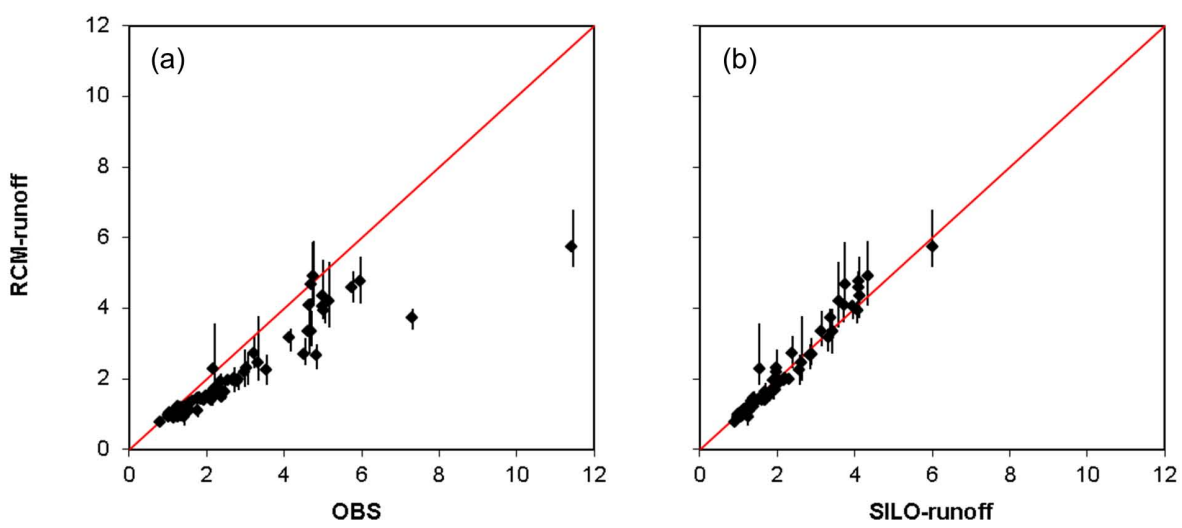

Fig. 7. Comparison of coefficients of variation (CV) of daily streamflows generated by SIMHYD at 86 streamflow gauges for $1961-2007$. (a) CV of daily streamflows generated by SIMHYD forced with the RCM (RCM-runoff) and observations (OBS). (b) CV of daily streamflows generated by RCM-runoff and SIMHYD forced with SILO (SILO-runoff). Points show the mean of the six RCM simulations, bars show the range from the six simulations.

\subsubsection{SIMHYD model performance}

SIMHYD exhibited the lowest biases of the hydrological models, and accordingly we focus on SIMHYD projections to report changes to future streamflows. We describe several additional performance tests of the SIMHYD model here.

SIMHYD RCM-runoff tends to underestimate the daily variance (measured as the coefficient of variation, CV) of observed streamflows at the 86 gauge sites (Fig. 7a). However, when daily CV of SIMHYD RCM-runoff is compared to daily $\mathrm{CV}$ of SIMHYD SILO-runoff at the same sites, there is strong agreement (Fig. 7b). This implies that the tendency of SIMHYD RCM-runoff to underestimate daily $\mathrm{CV}$ of observed runoff is not caused by the RCM or the bias-correction, but rather by the SILO dataset or the SIMHYD hydrological models, as calibrated for our study. The bias-corrected RCM inputs reproduce a similar level of variability to that present in SILO rainfalls for the purposes of hydrological modelling.

SIMHYD RCM-runoff matches observed seasonal streamflows reasonably well (Fig. 8). Seasonal streamflows are particularly closely matched in northern and western catchments, illustrated by the Black River and Rubicon River. In the central, western and southern catchments (Nive, Franklin and Huon Rivers) SIMHYD RCM-runoff tends to underpredict gauged streamflows from September to December. This difference is also present in the SIMHYD SILOrunoff (black line in Fig. 8), indicating that it is caused by 


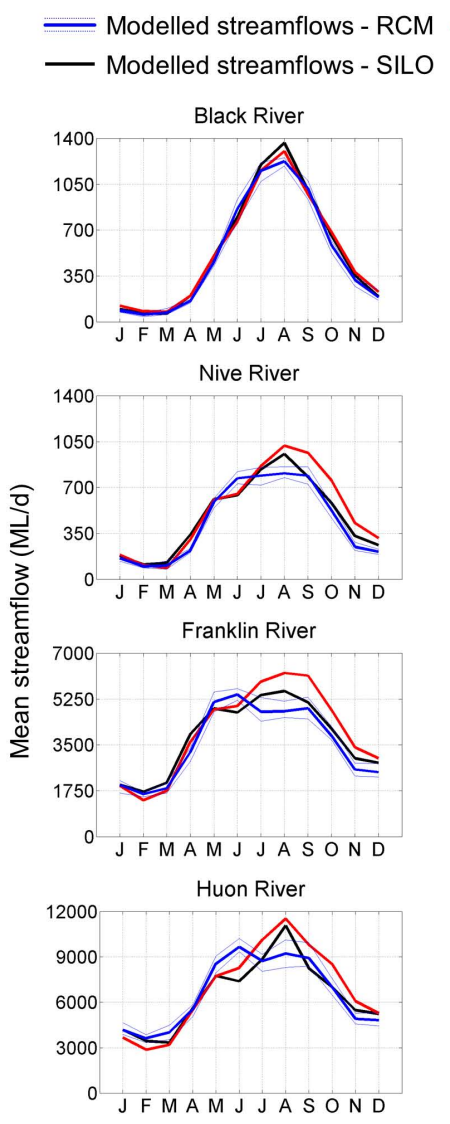

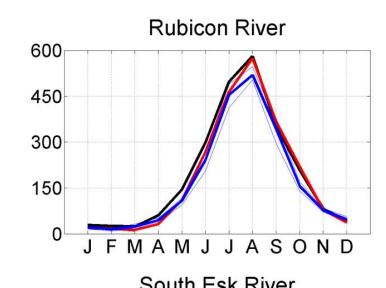
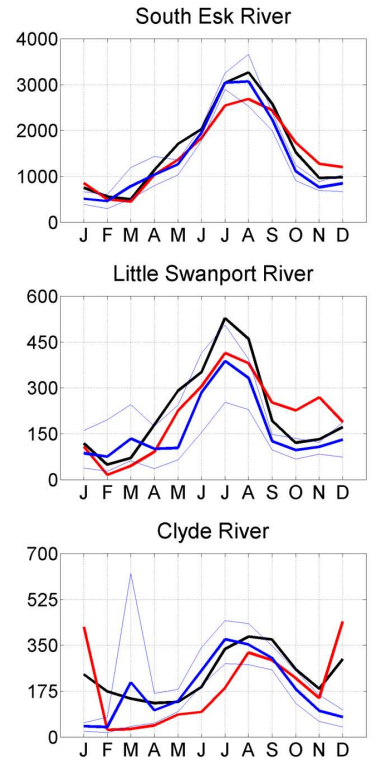

Fig. 8. Comparison of mean monthly modelled and gauged streamflows for 1961-2007. Blue line shows streamflows modelled with SIMHYD forced by the RCM, faint blue lines give range of the six RCM simulations, black line shows SIMHYD forced by SILO and red line shows gauged streamflows.

hydrological model calibration or the SILO rainfalls rather than the bias-corrected RCM inputs. SIMHYD RCM-runoff varied much more between RCM simulations in the drier eastern catchments (South Esk, Little Swanport and Clyde rivers) than in the wetter western and southern catchments (Black River, Franklin River and Huon River). This is consistent with the higher variability of rainfall in eastern Tasmania. The summer (DJF) yields of the Clyde River are difficult to replicate as the upper reaches of this catchment are impounded (Lake Crescent/Sorell) and regulated for irrigation.

The effects of the bias-corrected RCM inputs on hydrological performance are more easily seen in streamflow duration curves (Fig. 9). In general, SIMHYD RCM-runoff underestimates larger streamflows modelled with SIMHYD SILO-runoff. This is most probably caused by the inadequate replication of the temporal characteristics of rainstorms by the bias-corrected RCM outputs, already described. In catchments with high rainfalls, SIMHYD SILOrunoff tends to underestimate larger (exceedance probabilities $<10 \%$ ) observed streamflows (Black River, Nive River,

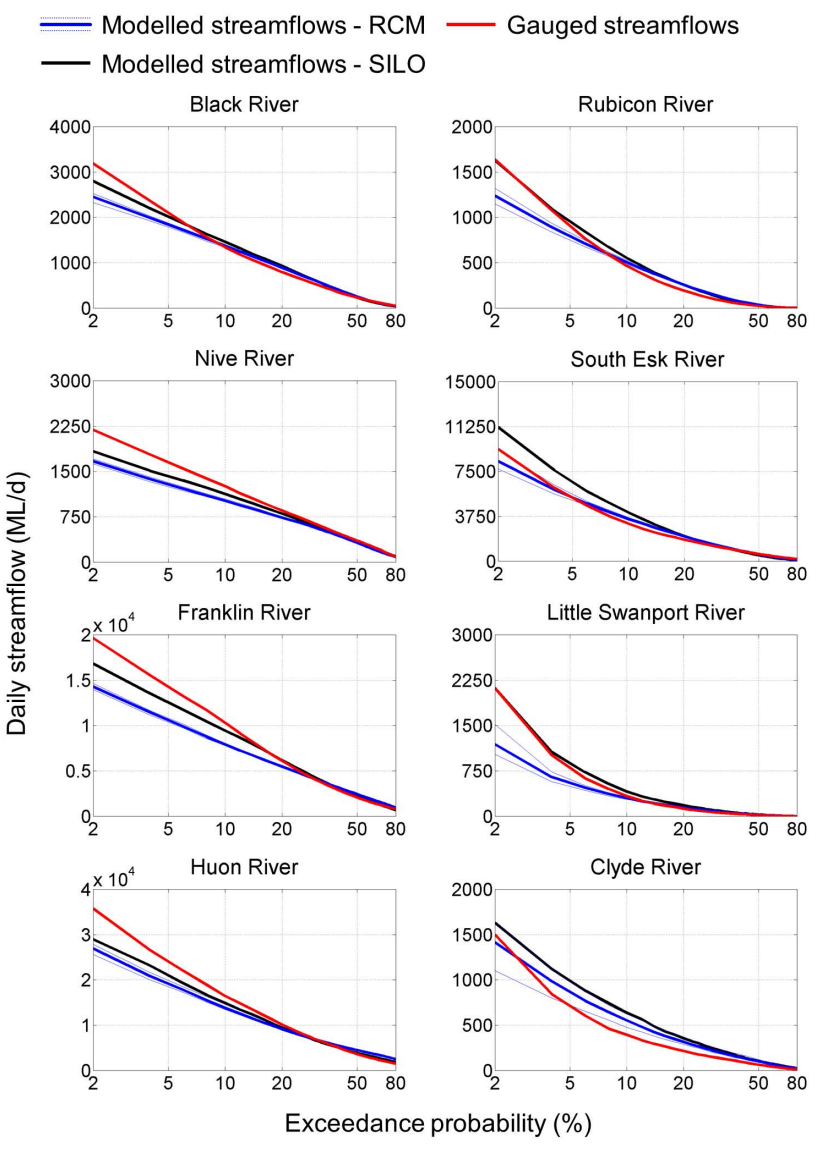

Fig. 9. Comparison of streamflow durations for observed and modelled daily streamflows 1961-2007. Blue line shows streamflows modelled with SIMHYD forced by the RCM, faint blue lines give range of the six RCM simulations, black line shows SIMHYD forced by SILO and red line shows gauged streamflows.

Franklin River, Huon River), and this tendency is exacerbated in SIMHYD RCM-runoff. Despite this, larger streamflows generated by SIMHYD SILO-runoff are reasonably well replicated by SIMHYD RCM-runoff in several of the wetter catchments (Black River, Nive River, Huon River). In catchments where SIMHYD SILO-runoff overestimates larger observed streamflows (South Esk River, Clyde River), the SIMHYD RCM-runoff offers a closer match to observed streamflows than SIMHYD SILO-runoff. As with low flows, alternative hydrological models or calibration methods could have improved replication of large daily streamflows in catchments where the hydrological models did not perform well. In all catchments, SIMHYD SILO-runoff medium streamflows (exceedance probabilities of $10 \%-80 \%$ ) are reasonably well replicated by SIMHYD RCM-runoff. Overall, SIMHYD RCM-runoff replicates the range of observed streamflows and SIMHYD SILO-runoff reasonably well. 

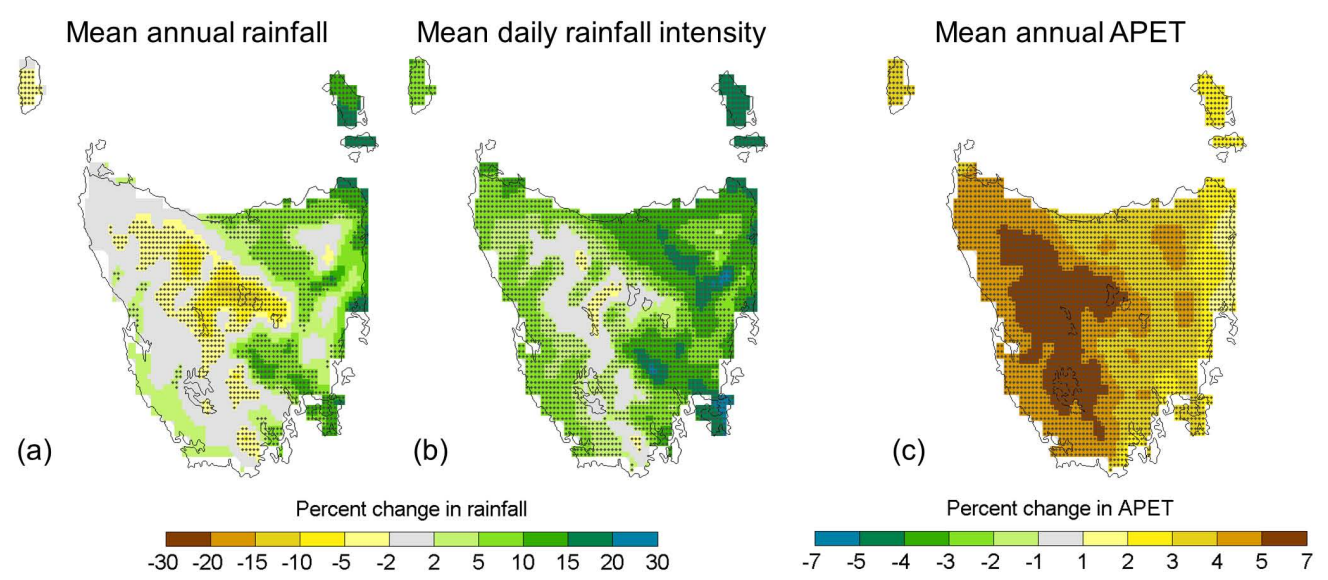

Fig. 10. Change in rainfall and APET from 1961-1990 to 2070-2099. (a) Change in mean annual rainfall. (b) Change in mean daily rainfall intensity for rain days $>1 \mathrm{~mm}$. (c) Change in mean annual APET. All plots are calculated from the average of the six RCM simulations. Stippling shows regions where at least five of the six RCM simulations agree on the sign of change.

\subsection{Projected changes in rainfall and APET}

Projected changes in rainfall and APET from 1961-1990 to 2070-2099 calculated from the mean of the six RCM simulations are shown in Fig. 10. Changes in mean annual rainfall vary spatially. Reductions in mean annual rainfall are projected for the mountainous centre (down to $-15 \%$ ), but marked increases (up to $30 \%$ ) are projected in the east. The increases in the east tend to occur at lower elevations. An increase in mean annual rainfall is also projected along the south-west coast. The simulations agree strongly on the sign of change in the lower-lying parts of the east coast, and at high elevations in the mountainous centre (Fig. 10a).

Mean annual APET is projected to increase across Tasmania, with the highest increases in the western mountains (Fig. 10c). Increases in APET are small compared to changes in mean annual rainfall, with mean annual APET increases always less than $7 \%$. All RCM simulations project Tasmania-wide increases in APET by 2070-2099.

Mean daily rainfall intensity is projected to increase over most of Tasmania (Fig. 10b). The largest proportional increases occur in the east $(>15 \%)$. RCM simulations show strong agreement on the sign of change in mean daily rainfall intensity for much of Tasmania (Fig. 10b). The general tendency of rain to fall in fewer, more intense events as the climate warms is a robust feature of theory, simulations and observations (Allen and Ingram, 2002; Pall et al., 2007; Allan and Soden, 2008; Min et al., 2011) and is at least partly consistent with an increase in atmospheric moisture (Hegerl et al., 2004; Stephens and Hu, 2010).

\subsection{Projected changes in runoff and streamflows}

In describing projections we distinguish between "runoff", defined as gridded outputs from the hydrological models, and "streamflows", calculated by aggregating runoff to river catchments.

\subsubsection{Variation between hydrological models and RCMs}

Projected changes to future runoff vary much more between RCM simulations than between hydrological models. For a given RCM simulation, future changes to mean annual runoff projected with AWBM, Sacramento, SIMHYD and SMAR-G are very similar (Fig. 11). Using the downscaled GFDL-CM2.1 simulation as an example, AWBM, Sacramento, SIMHYD and SMAR-G agree strongly on the spatial features of runoff change (Fig. 11). The four hydrological models show drying in central and north-west Tasmania, little change in the south-west, and wetting in the east. AWBM, Sacramento, SIMHYD and SMAR-G are also consistent in seasonal projections and in projections of low and high streamflows (not shown). IHACRES projects more intense and more widespread wetting than other hydrological models for all RCM simulations. In the downscaled GFDLCM2.1 example, IHACRES projects more intense wetting in the east and stronger wetting in the west and southwest than the other hydrological models. The high sensitivity of IHACRES to changes in inputs renders suspect the projections of Tasmanian runoff from IHACRES with biascorrected RCM inputs.

\subsubsection{Projections from the SIMHYD hydrological model}

In many areas, the projected changes to rainfall are amplified in changes to runoff. Where mean annual rainfall in central Tasmania decreases by up to $15 \%$ (Fig. 10a), runoff decreases by more than $30 \%$ (Fig. 12a). In eastern Tasmania, 

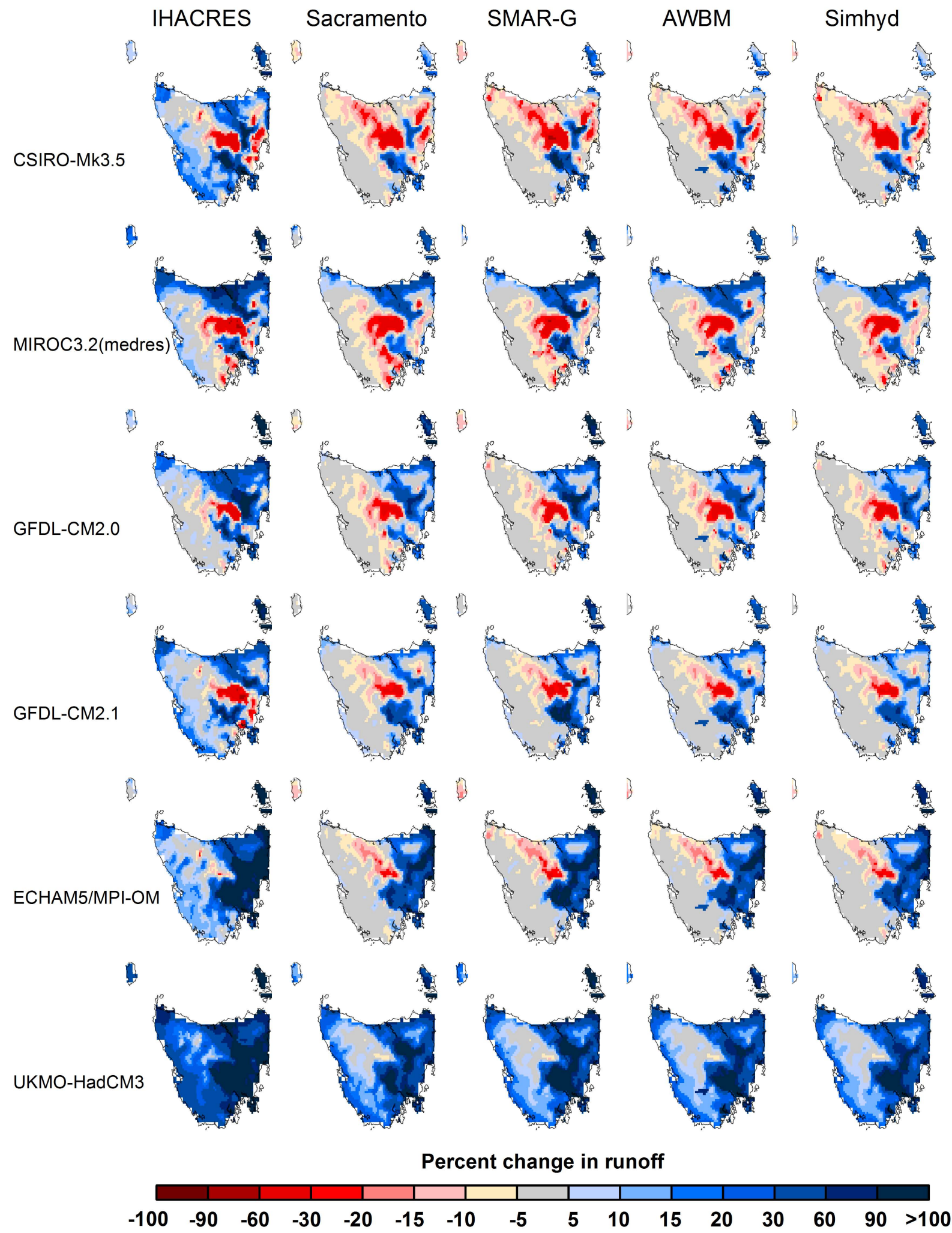

Fig. 11. Change in mean annual runoff from 1961-1990 to 2070-2099 for all RCM simulations and hydrological models. RCM simulations are designated by the GCMs used for downscaling, and are ordered from driest projection (CSIRO-Mk3.5, top) to wettest projection (UKMOHadCM3, bottom). Hydrological models are ordered from most biased (IHACRES, left) to least biased (SIMHYD, right). 

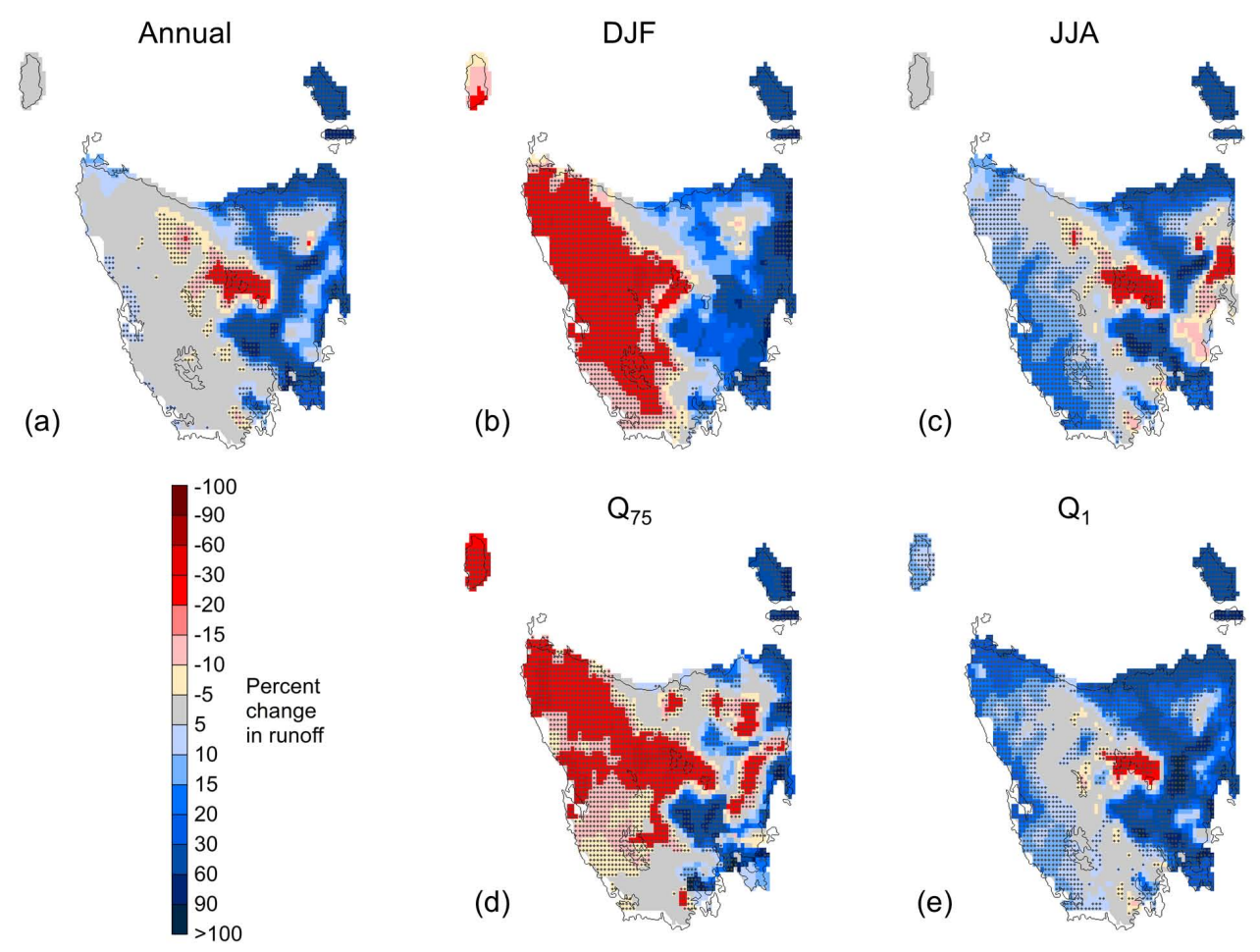

Fig. 12. Change in runoff simulated by SIMHYD from 1961-1990 to 2070-2099. (a) Change in mean annual runoff. (b) Change in mean DJF runoff. (c) Change in mean JJA runoff. (d) Change in $Q_{75}$ runoff. (e) Change in $Q_{1}$ runoff. Changes are calculated from the mean of the six RCM simulations. Stippling shows regions where at least five of the six RCM simulations agree on the sign of change.

rainfall increases of $<20 \%$ (Fig. 10a) are projected to increase runoff by $>60 \%$ (Fig. 12a).

Low runoff events generally decrease more than mean runoff, while high runoff events increase similarly to mean runoff. The RCM simulations agree strongly on a decrease in low runoff (represented by runoff with $75 \%$ exceedance probability, $Q_{75}$ ) over most of Tasmania (Fig. 12d). $Q_{75}$ runoff decreases more and over a wider area than decreases to mean runoff (Fig. 12d). Increases in high runoff (represented by runoff with $1 \%$ exceedance probability, $Q_{1}$ ) are more widespread and show similar proportional increases to mean runoff (Fig. 12e). The RCM simulations agree strongly on an increase in $Q_{1}$ runoff over the west coast, north and east. Because $Q_{1}$ runoff events are larger than mean runoff events, a proportional change in $Q_{1}$ runoff equates to a much greater increase in streamflow than the same proportional change to mean runoff.

Changes in seasonal streamflow projected with SIMHYD at the eight study catchments are shown in Fig. 13. Projected changes to streamflows vary considerably by season. DJF runoff decreases markedly in the west (Fig. 12b), however these seasonal decreases have little effect on annual streamflows in the Black and Franklin rivers as DJF runoff makes a small contribution to streamflow in these rivers. Similar seasonal changes are also projected in the Huon River in the south-west. The Rubicon River in the central north of
Tasmania is projected to experience increases in streamflows in all seasons, particularly JJA (Fig. 13).

Projections for rivers in the drier regions, including the north-east (South Esk River), east (Little Swanport River) and centre (Clyde River), are characterised by a high degree of variation between RCM simulations. The South Esk River and Little Swanport River are projected to experience increases in streamflow (Fig. 13), largely during February to April.

A major feature of these projections is reduced runoff over Tasmania's central mountains in all seasons (Fig. 12a-c). This contrasts with projected increases in mean annual runoff in many low-elevation areas in the east and in coastal areas (Fig. 12a). The high-elevation Nive River catchment is projected to experience decreases in streamflow year round, particularly in May and June (Fig. 13). Catchments in central Tasmania that span both high and low elevations (e.g. Clyde River) show complex responses. The Clyde River is projected to experience year-round streamflow decreases in high elevation areas (not shown), but these decreases are offset by projected increases at lower elevations, particularly during MAM, resulting in increased mean annual streamflow at the catchment outlet. A similar elevation-sensitive streamflow response is observed for the South Esk River in the north-east. 


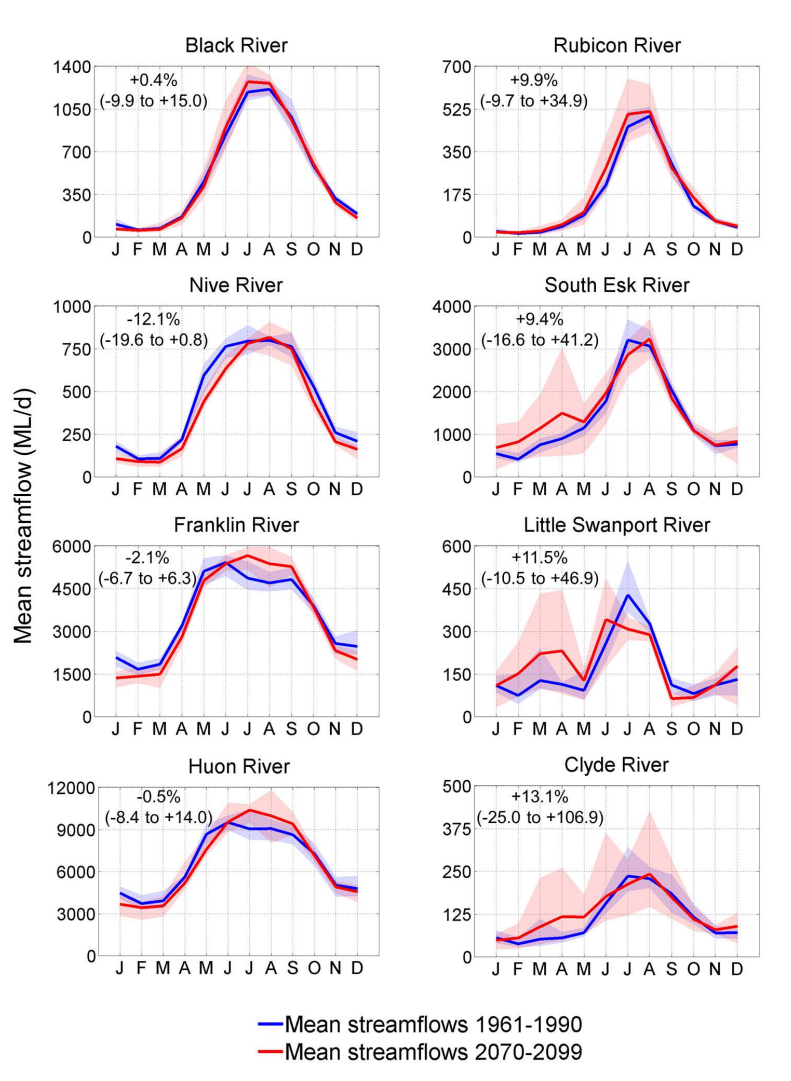

Fig. 13. Mean monthly streamflows simulated by SIMHYD for 1961-1990 and 2070-2099. Shaded confidence intervals show range of the six RCM simulations. Numbers in plots give percent change in mean annual streamflow from the average of the six RCM simulations. Numbers in brackets give the range of percent change from the six simulations.

Variance in daily and annual runoff is projected to increase in many areas of Tasmania. Increases in the variance of daily runoff occur in the northern two-thirds of Tasmania (Fig. 14a), and the RCM simulations agree strongly on projected increases in CV of daily runoff over much of Tasmania. The most marked increases in daily variance occur in the lowlands of the central east, which is consistent with an increase in mean daily rainfall intensity (Fig. 10b). Variance in annual runoff increases over most areas, with the most notable increases projected for the north-west and central highlands (Fig. 14b).

Overall, the projections suggest that there will be a greater variability of streamflows, with rivers rising to higher peaks and experiencing longer periods of low streamflow.

\section{Discussion and conclusions}

Our study demonstrates that quantile mapping can directly couple RCM outputs to hydrological models to produce realistic streamflows in a majority of catchments. Our method

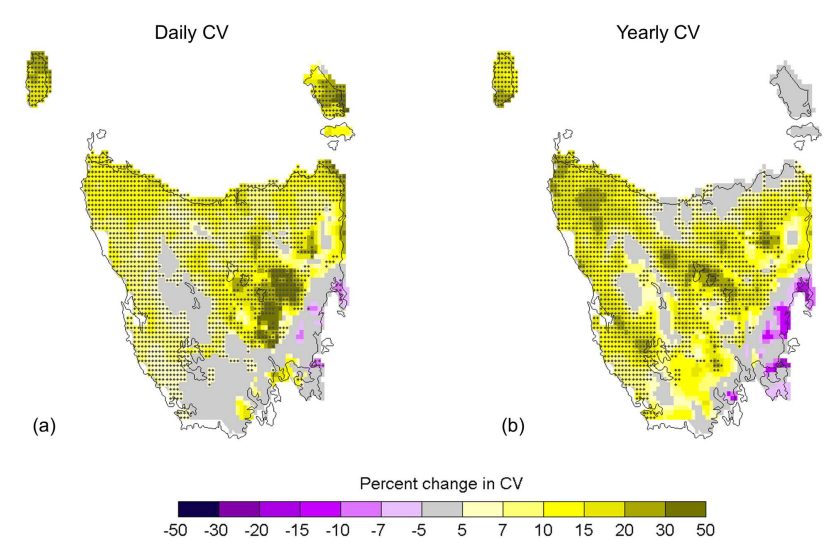

Fig. 14. Changes to coefficient of variation (CV) of runoff simulated by SIMHYD from 1961-1990 to 2070-2099. (a) Changes to CV of daily runoff. (b) Changes to $\mathrm{CV}$ of annual runoff. Changes are calculated from the average of the six RCM simulations. Stippling shows regions where at least five of the six RCM simulations agree on the sign of change.

did not perform as well in eastern Tasmanian catchments, which are subject to higher rainfall variability. In these catchments, the poorer performance is explained largely by the bias-corrected RCM rainfalls not being sufficiently similar to observations.

We note that our method of quantile mapping may be more sensitive to changes in training period than comparable methods that fit probability distributions to observations and models before quantile mapping (e.g. Li et al., 2010). Fitting probability distributions has the advantage of smoothing frequency distributions, which may reduce variation in quantile mapping factors with changes in training period. However, Li et al. (2010) found quantile mapping varied noticeably with changes in training period, despite having fitted probability distributions before calculating their bias-corrections. Further, fitting probability distributions adds parameter uncertainties, and using empirical cumulative frequency distributions has the virtue of simplicity. Nonetheless, we reiterate that long training periods are required to generate temporally stable cumulative frequency distributions. We recommend the use of cross-validation testing as a routine measure to demonstrate the stability of quantile mapping.

The IHACRES hydrological model does not replicate observed runoff as realistically as the other hydrological models with bias-corrected RCM inputs. Further, IHACRES gives different projections of change. Viney et al. (2009a) found that IHACRES was the best performing model when calibrated, but performed worst under spatial cross-validation tests. They attributed this drop in performance to the IHACRES parameter that scales rainfall. In contrast, Vaze et al. (2010) found that IHACRES was not particularly sensitive to changes in inputs when calibrated to a range of wet and dry conditions for catchments on continental Australia. 
We conclude that for studies using bias-corrected RCM variables as direct inputs to hydrological models for impact studies, it is important to test a hydrological model for sensitivity to changes in inputs as a precursor to generating stable, plausible runoff projections, even if the model has been shown to be effective for climate studies elsewhere.

Projected changes in Tasmanian runoff vary far more between RCM simulations than between hydrological models. This finding is accentuated if we exclude the poorly performing IHACRES model from the projections. For our study, therefore, it is more important to consider the range of RCM simulations than the range of hydrological models to adequately describe uncertainty in projections of surface water availability. This finding supports several other studies that have shown climate models to be a more significant source of uncertainty than hydrological models for surface water projections (Wilby and Harris, 2006; Prudhomme and Davies, 2009; Teng et al., 2011).

Our fine-scale simulations project changes to Tasmanian runoff to vary considerably by region, in contrast to near-uniform spatial changes projected by GCMs (Christensen et al., 2007). Of note are the year-round decreases in runoff projected for the central mountains, as Tasmania relies on streamflows from this region to generate hydro-electric power and to supply irrigators. The projected decrease in runoff over the central mountains of Tasmania reported here has seasonal dependence. For winter in the future, the air is warmer and moister as it approaches the west coast of Tasmania. This causes an increase in rainfall along the west coast, which leads to increased upward motion along the western slopes of the mountains. After reaching the highest elevations, the air descends, and at a greater rate in the future as a response to the increased upward motion further west. This tendency for subsidence causes a slight decrease in rainfall in the central plateau region. In the other seasons, the decreased westerly airflow projected in the future results in weaker upward motion, and rainfall, along the western slopes. This decrease in rainfall extends to the central mountains. In addition, with decreased clouds and warmer temperatures, the surface dries out relative to the current climate (see APET changes). As a result, less moisture is available locally for evaporation. Thus for all seasons, runoff is projected to decrease in the central mountains relative to the lower-lying areas. Reduced streamflows from Tasmania's central mountains will reduce Tasmania's hydro-electric power generation capacity (Bennett et al., 2010).

The projected increases in runoff in eastern Tasmania reported here contrast with Post et al. (2012), whose median future scenario showed either no change or decreases in runoff in eastern Tasmania by 2030 . This difference in sign may be attributed to the increased resolution of land-ocean boundaries in CCAM in comparison to the GCM projections used by Post et al. (2012). The increases in eastern rainfall projected by CCAM result from a tendency for increased atmospheric blocking, southward extension of the East Australian
Current, and the formation of a small but significant mean sea level pressure anomaly in the Tasman Sea that enhances the onshore winds in this region (Grose et al., 2010). The pattern in the GCMs is similar but displaced further offshore to the south and east due to the coarser grid size of GCMs (Grose et al., 2011). Notwithstanding increased variability of streamflows (discussed below), increased surface water availability in Tasmania's east may present opportunities for future agricultural production.

Changes in seasonal runoff are an important feature of these projections. The projected decreases in DJF runoff over western Tasmania are caused by a reduction in the mean westerly circulation (Grose et al., 2010), associated with an expansion of the Hadley cell and a poleward movement of the mid-latitude storm tracks (Yin, 2005), including a poleward movement and strengthening of the subtropical ridge of high pressure and an increase in the high phase of the southern annular mode (Kushner et al., 2001). Even though reduced DJF streamflows in the west have little impact on annual streamflow volumes, these changes are likely to have deleterious effects on endemic freshwater fish (Morrongiello et al., 2011).

Increased runoff variability could have as great an impact on Tasmanian water management practices as changes to seasonal runoff. Projected increases to inter-annual variability in streams fed by the central highlands and western mountains could mean that the large hydropower and irrigation storages situated in these areas may not be able to buffer periods of low inflows as effectively in future as they have in the past. Projected increases in runoff occur largely in the east in lowland areas, where water is presently stored mostly in small farm dams. Small dams may be less able to buffer the projected increases in annual variability, even if there is more water available on average. In short, the projected increases in runoff may not easily be captured by current infrastructure.

The implications for Tasmanian surface water availability and storage illustrate the virtue of using an ensemble of high-resolution RCM projections as direct inputs to hydrological models to understand the nature of future surface water changes in a warmer world. These implications cannot easily be addressed through the more common approach of perturbing historical climate data that assumes that rainfall variability is unchanged in the future. A large amount of effort has been expended in Australia in recent years building complex series of hydrological models to assess climate change impacts from pattern scaling of GCMs (Petheram et al., 2009; Chiew et al., 2009; Charles et al., 2010). Our study has shown that there is the potential to update these studies using high-resolution RCM simulations when these become available for other regions of Australia.

Acknowledgements. This work was part of the Climate Futures for Tasmania project (CFT) (http://www.acecrc.org.au/Research/ Climate\%20Futures). CFT was made possible through funding and research support from a consortium of state and national partners. 
The work was supported by the Australian government's Cooperative Research Centres Program through the ACE CRC.

We acknowledge J. L. McGregor (CMAR) for assistance in running the RCM simulations. C. J. White (Bureau of Meteorology), W. F. Budd (ACE CRC) and S. Wotherspoon (IMAS) provided advice and assistance. J. Teng (CLW) provided the evapotranspiration algorithms. A. Yang (CLW) provided assistance with some of the hydrological modelling software. K. Michael (IMAS) provided useful comments on an earlier draft.

We thank Anas Ghadouani and two anonymous referees for their considered and constructive comments.

We acknowledge the modelling groups, the Program for Climate Model Diagnosis and Intercomparison (PCMDI) and the WCRP's Working Group on Coupled Modelling (WGCM) for their roles in making available the WCRP CMIP3 multi-model dataset. Support of this dataset is provided by the Office of Science, US Department of Energy.

Edited by: A. Ghadouani

\section{References}

Akhtar, M., Ahmad, N., and Booij, M. J.: Use of regional climate model simulations as input for hydrological models for the Hindukush-Karakorum-Himalaya region, Hydrol. Earth Syst. Sci., 13, 1075-1089, doi:10.5194/hess-13-1075-2009, 2009.

Allan, R. P. and Soden, B. J.: Atmospheric warming and the amplification of precipitation extremes, Science, 321, 1481-1484, doi:10.1126/science.1160787, 2008.

Allen, M. R. and Ingram, W. J.: Constraints on future changes in climate and the hydrologic cycle, Nature, 419, 224-232, doi:10.1038/nature01092, 2002.

Ashfaq, M., Skinner, C. B., and Diffenbaugh, N. S.: Influence of SST biases on future climate change projections, Clim. Dynam., 36, 1303-1319, doi:10.1007/s00382-010-0875-2, 2010.

Bastola, S., Murphy, C., and Sweeney, J.: The role of hydrological modelling uncertainties in climate change impact assessments of Irish river catchments, Adv. Water Resour., 34, 562576, doi:10.1016/j.advwatres.2011.01.008, 2011.

Bennett, J. C., Ling, F. L. N., Graham, B., Corney, S. P., Holz, G. K., Grose, M. R., White, C. J., Post, D. A., Gaynor, S. M., and Bindoff, N. L.: Climate Futures for Tasmania: water and catchments, Antarctic Climate and Ecosystems Cooperative Research Centre, Hobart, 2010.

Bennett, J. C., Grose, M. R., Post, D. A., Ling, F. L. N., Corney, S. P., and Bindoff, N. L.: Performance of quantile-quantile biascorrection for use in hydroclimatological projections, MODSIM2011 International Congress on Modelling and Simulation, Perth, December, 2011.

Berbery, E. H. and Fox-Rabinovitz, M. S.: Multiscale Diagnosis of the North American Monsoon System Using a VariableResolution GCM, J. Climate, 16, 1929-1947, doi:10.1175/15200442(2003)016;1929:MDOTNA ¿2.0.CO;2, 2003.

Berg, P., Haerter, J. O., Thejll, P., Piani, C., Hagemann, S., and Christensen, J. H.: Seasonal characteristics of the relationship between daily precipitation intensity and surface temperature, Geophys. Res. Lett., 114, D18102, doi:10.1029/2009JD012008, 2009.
Boé, J. and Terray, L.: A weather-type approach to analyzing winter precipitation in France: twentieth-century trends and the role of anthropogenic forcing, J. Climate, 21, 3118-3133, doi:10.1175/2007JCLI1796.1, 2007.

Boé, J., Terray, L., Habets, F., and Martin, E.: Statistical and dynamical downscaling of the Seine basin climate for hydrometeorological studies, Int. J. Climatol., 27, 1643-1655, 2007.

Boughton, W. C.: The Australian water balance model, Environ. Modell. Softw., 19, 943-956, doi:10.1016/j.envsoft.2003.10.007, 2004.

Burnash, R. J. C., Ferral, R. L., and McGuire, R. A.: A generalized streamflow simulation system-conceptual modeling for digital computers, Joint Federal and State River Forecast Center, Sacramento, 204 pp., 1973.

Charles, S. P., Bari, M. A., Kitsios, A., and Bates, B. C.: Effect of GCM bias on downscaled precipitation and runoff projections for the Serpentine catchment, Western Australia, Int. J. Climatol., 27, 1673-1690, doi:10.1002/joc.1508, 2007.

Charles, S. P., Silberstein, R., Teng, J., Fu, G., Hodgson, G., Gabrovsek, C., Crute, J., Chiew, F. H. S., Smith, I. N., Kirono, D. G. C., Bathols, J. M., Li, L. T., Yang, A., Donohue, R. J., Marvanek, S. P., McVicar, T. R., Van Niel, T. G., and Cai, W.: Climate analyses for south-west Western Australia. A report to the Australian Government from the CSIRO South-West Western Australia Sustainable Yields Project, CSIRO, Australia, 2010.

Chiew, F. H. S., Peel, M. C., and Western, A. W.: Application and testing of the simple rainfall-runoff model SIMHYD, in: Mathematical models of small watershed hydrology and applications, edited by: Singh, V. P. and Frevert, D. K., Water Resources Publications, Littleton, USA, 335-367, 2002.

Chiew, F. H. S., Teng, J., Vaze, J., Post, D. A., Perraud, J. M., Kirono, D. G. C., and Viney, N. R.: Estimating climate change impact on runoff across southeast Australia: Method, results and implications of the modeling method, Water Resour. Res., 45, W10414, doi:10.1029/2008WR007338, 2009.

Chiew, F. H. S., Kirono, D. G. C., Kent, D. M., Frost, A. J., Charles, S. P., Timbal, B., Nguyen, K. C., and Fub, G.: Comparison of runoff modelled using rainfall from different downscaling methods for historical and future climates, J. Hydrol., 387, 10-23, doi:10.1016/j.jhydrol.2010.03.025, 2010.

Christensen, J. H., Hewitson, B., Busuioc, A., Chen, A., Gao, X., Held, I., Jones, R., Kolli, R. K., Kwon, W.-T., Laprise, R., Magaña Rueda, V., Mearns, L., Menéndez, C. G., Räisänen, J., Rinke, A., Sarr, A., and Whetton, P.: Regional Climate Projections, in: Climate Change 2007: The Physical Science Basis, edited by: Solomon, S., Qin, D., Manning, M., Chen, Z., Marquis, M., Averyt, K. B., Tignor, M., and Miller, H. L., Cambridge University Press, Cambridge, United Kingdom and New York, NY, USA, 2007.

Corney, S. P., Katzfey, J. J., McGregor, J. L., Grose, M. R., White, C. J., Holz, G. K., Bennett, J. C., Gaynor, S. M., and Bindoff, N. L.: Climate Futures for Tasmania: methods and results on climate modelling, Antarctic Climate and Ecosystems Cooperative Research Centre, Hobart, 2010.

Engelbrecht, F. A., McGregor, J. L., and Engelbrecht, C. J.: Dynamics of the Conformal-Cubic Atmospheric Model projected climate-change signal over southern Africa, Int. J. Climatol., 29, 1013-1033, doi:10.1002/joc.1742, 2009. 
Fowler, H. J. and Kilsby, C. G.: Using regional climate model data to simulate historical and future river flows in northwest England, Climatic Change, 80, 337-367, doi:10.1007/s10584-006-9117-3, 2007.

Fox-Rabinovitz, M., Côté, J., Dugas, B., Déqué, M., McGregor, J. L., and Belochitski, A.: Stretched-Grid Model Inter-comparison Project: decadal regional climate simulations with enhanced variable and uniform-resolution GCMs, Meteorol. Atmos. Phys., 100, 159-177, doi:10.1007/s00703-008-0301-z, 2008.

Goswami, M., O'Connor, K. M., and Shamseldin, A. Y.: Structures and performances of five rainfall-runoff models for continuous river-flow simulation, 1st Biennial Meeting of International Environmental Modeling and Software Society, Lugano, Switzerland, 2002.

Graham, L. P., Hagemann, S., Jaun, S., and Beniston, M.: On interpreting hydrological change from regional climate models, Climatic Change, 81, 97-122, doi:10.1007/s10584-006-9217-0, 2007.

Grose, M. R., Barnes-Keoghan, I., Corney, S. P., White, C. J., Holz, G. K., Bennett, J. C., Gaynor, S. M., and Bindoff, N. L.: Climate Futures for Tasmania: general climate, Antarctic Climate and Ecosystems Cooperative Research Centre, Hobart, 2010.

Grose, M. R., Corney, S. P., Katzfey, J. J., Bennett, J. C., and Bindoff, N. L.: Improving projections of rainfall trends through regional climate modeling and wide-ranging assessment, MODSIM2011 International Congress on Modelling and Simulation, Perth, December, 2011.

Hegerl, G. C., Zwiers, F. W., Stott, P. A., and Kharin, V. V.: Detectability of anthropogenic changes in annual temperature and precipitation extremes, J. Climate, 17, 3683-3700, doi:10.1175/1520-0442(2004)017;3683:DOACIA $i 2.0 . C O ; 2$, 2004.

Held, I. M. and Soden, B. J.: Robust responses of the hydrological cycle to global warming, J. Climate, 19, 5686-5699, 2006.

Ines, A. V. M. and Hansen, J. W.: Bias correction of daily GCM rainfall for crop simulation studies, Agr. Forest Meteorol., 138, 44-53, doi:10.1016/j.agrformet.2006.03.009, 2006.

Jeffrey, S. J., Carter, J. O., Moodie, K. M., and Beswick, A. R.: Using spatial interpolation to construct a comprehensive archive of Australian climate data, Environ. Modell. Softw., 16, 309-330, doi:10.1016/S1364-8152(01)00008-1, 2001.

Katzfey, J. J., McGregor, J., Nguyen, K. C., and Thatcher, M.: Dynamical downscaling techniques: impacts on regional climate change signals, 18th World IMACS Congress and MODSIM09 International Congress on Modelling and Simulation, Cairns, July, 2009.

Kendon, E. J., Rowell, D. P., and Jones, R. G.: Mechanisms and reliability of future projected changes in daily precipitation, Clim. Dynam., 35, 489-509, doi:10.1007/s00382-009-0639-z, 2010.

Kilsby, C. G. (Ed.): Sustainable Water: Uncertainty, Risk and Vulnerability in Europe, Context and aims, Special Issue, Hydrol. Earth Syst. Sci., http://www.hydrol-earth-syst-sci.net/special_ issue80.html, 2007.

Kilsby, C. G., Tellier, S. S., Fowler, H. J., and Howels, T. R.: Hydrological impacts of climate change on the Tejo and Guadiana Rivers, Hydrol. Earth Syst. Sci., 11, 1175-1189, doi:10.5194/hess-11-1175-2007, 2007.

Kushner, P. J., Held, I. M., and Delworth, T. L.: Southern hemisphere atmospheric circulation response to global warming, J. Climate, 14, 2238-2249, doi:10.1175/15200442(2001)014;0001:SHACRT ¿2.0.CO;2, 2001.

Lal, M., McGregor, J. L., and Nguyen, K. C.: Very high-resolution climate simulation over Fiji using a global variable-resolution model, Clim. Dynam., 30, 293-305, doi:10.1007/s00382-0070287-0, 2008.

Li, H., Sheffield, J., and Wood, E. F.: Bias correction of monthly precipitation and temperature fields from Intergovernmental Panel on Climate Change AR4 models using equidistant quantile matching, J. Geophys. Res., 115, D10101, doi:10.1029/2009JD012882, 2010.

Mailhot, A., Duchesne, S., Caya, D., and Talbot, G.: Assessment of future change in intensity-duration-frequency (IDF) curves for Southern Quebec using the Canadian Regional Climate Model (CRCM), J. Hydrol., 347, 197-210, doi:10.1016/j.jhydrol.2007.09.019, 2007.

McGregor, J. L. and Dix, M. R.: An updated description of the conformal-cubic atmospheric model, in: High Resolution $\mathrm{Nu}-$ merical Modelling of the Atmosphere and Ocean, edited by: Hamilton, K. and Ohfuchi, W., Springer, New York, 51-76, 2008.

Meehl, G., Covey, A., C., Delworth, T., Latif, M., McAvaney, B., Mitchell, J. F. B., Stouffer, R. J., and Taylor, K. E.: The WCRP CMIP3 multi-model dataset: A new era in climate change research, B. Am. Meteorol. Soc., 88, 1383-1394, doi:10.1175/BAMS-88-9-1383, 2007.

Merz, R., Parajka, J., and Blöschl, G.: Time stability of catchment model parameters: implications for climate impact analyses, Water Resour. Res., 47, W02531, doi:10.1029/2010WR009505, 2011.

Min, S.-K., Zhang, X., Zwiers, F. W., and Hegerl, G. C.: Human contribution to more-intense precipitation extremes, Nature, 470, 378-381, doi:10.1038/nature09763, 2011.

Mitchell, T.: Pattern scaling, Climatic Change, 60, 217-242, doi:10.1023/A:1026035305597, 2003.

Morrongiello, J. R., Beatty, S. J., Bennett, J. C., Crook, D. A., Ikedife, D. N. E. N., Kennard, M. J., Kerezsy, A., Lintermans, M., McNeil, D. G., Pusey, B. J., and Rayner, T.: Climate change and its implications for Australia's freshwater fish, Mar. Freshwater Res., 62, 1082-1098, doi:10.1071/MF10308, 2011.

Morton, F. I.: Operational estimates of areal evapotranspiration and their significance to the science and practice of hydrology, J. Hydrol., 66, 1-76, doi:10.1016/0022-1694(83)90177-4, 1983.

Nakićenović, N. and Swart, R.: Special Report on Emissions Scenarios. A Special Report of Working Group III of the Intergovernmental Panel on Climate Change, Cambridge, United Kingdom, 570 pp., 2000.

Nguyen, K. C., Katzfey, J. J., and McGregor, J. L.: Global 60 km simulations with CCAM: evaluation over the tropics, Clim. Dynam., online first: doi:10.1007/s00382-011-1197-8, 2011.

Oki, T. and Kanae, S.: Global hydrological cycles and world water resources, Science, 313, 1068-1072, doi:10.1126/science.1128845, 2006.

Pall, P., Allen, M. R., and Stone, D. A.: Testing the Clausius-Clapeyron constraint on changes in extreme precipitation under $\mathrm{CO}_{2}$ warming, Clim. Dynam., 28, 351-363, doi:10.1007/s00382-006-0180-2, 2007.

Petheram, C., Hughes, D., Rustomji, P., Smith, K., Van Neil, T., and Yang, A.: River modelling for Northern Australia. A report to the Australian Government from the CSIRO Northern Australia 
Sustainable Yields Project, Australia, 2009.

Piani, C., Haerter, J., and Coppola, E.: Statistical bias correction for daily precipitation in regional climate models over Europe, Theor. Appl. Climatol., 99, 187-192, doi:10.1007/s00704-0090134-9, 2010a.

Piani, C., Weedon, G. P., Best, M., Gomes, S. M., Viterbo, P., Hagemann, S., and Haerter, J. O.: Statistical bias correction of global simulated daily precipitation and temperature for the application of hydrological models, J. Hydrol., 395, 199-215, doi:10.1016/j.jhydrol.2010.10.024, 2010b.

Post, D. A. and Jakeman, A. J.: Predicting the daily streamflow of ungauged catchments in SE Australia by regionalising the parameters of a lumped conceptual rainfall-runoff model, Ecol. Model., 123, 91-104, doi:10.1016/S0304-3800(99)001258, 1999.

Post, D. A., Chiew, F. H. S., Teng, J., Viney, N. R., Ling, F. L. N., Harrington, G., Crosbie, R. S., Graham, B., Marvanek, S., and McLoughlin, R.: A robust methodology for conducting largescale assessments of current and future water availability and use: a case study in Tasmania, Australia, J. Hydrol., 412-413, 233-245, doi:10.1016/j.jhydrol.2011.02.011, 2012.

Prudhomme, C. and Davies, H.: Assessing uncertainties in climate change impact analyses on the river flow regimes in the UK. Part 1: baseline climate, Climatic Change, 93, 177-195, doi:10.1007/s10584-008-9464-3, 2009.

Randall, D. A., Wood, R. A., Bony, S., Colman, R., Fichefet, T., Fyfe, J., Kattsov, V., Shukla, A. P. J., Srinivasan, J., Stouffer, R. J., Sumi, A., and Taylor, K. E.: Climate models and their evaluation, in: Climate Change 2007: The Physical Science Basis. Contribution of Working Group I to the Fourth Assessment Report of the Intergovernmental Panel on Climate Change, edited by: Solomon, S., Qin, D., Manning, M., Chen, Z., Marquis, M., Averyt, K. B., Tignor, M., and Miller, H. L., Cambridge University Press, Cambridge, United Kingdom, New York, USA, 2007.

Reynolds, R. W.: A real-time global sea surface temperature analysis, J. Climate, 1, 75-86, 1988.

Staudinger, M., Stahl, K., Seibert, J., Clark, M. P., and Tallaksen, L. M.: Comparison of hydrological model structures based on recession and low flow simulations, Hydrol. Earth Syst. Sci., 15, 3447-3459, doi:10.5194/hess-15-3447-2011, 2011.

Stephens, G. L. and Hu, Y.: Are climate-related changes to the character of global-mean precipitation predictable?, Environ. Res. Lett., 5, 025209, doi:10.1088/1748-9326/5/2/025209, 2010.

Tan, K. S., Chiew, F. H. S., Grayson, R. B., Scanlon, P. J., and Siriwardena, L.: Calibration of a daily rainfall-runoff model to estimate high daily flows, MODSIM 2005 International Congress on Modelling and Simulation, Melbourne, December, 2005.
Teng, J., Vaze, J., Chiew, F. H. S., Wang, B., and Perraud, J.-M.: Estimating the relative uncertainties sourced from GCMs and hydrological models in modelling climate change impact on runoff, J. Hydrometeorol., 13, 122-139, doi:10.1175/JHM-D-11-058.1, 2011.

Thatcher, M. and McGregor, J. L.: Using a scale-selective filter for dynamical downscaling with the Conformal Cubic Atmospheric Model, Mon. Weather Rev., 137, 1742-1752, doi:10.1175/2008MWR2599.1, 2009.

Thatcher, M. and McGregor, J. L.: A technique for dynamically downscaling daily-averaged GCM datasets using the Conformal Cubic Atmospheric Model, Mon. Weather Rev., 139, 79-95, doi:10.1175/2010MWR3351.1, 2011.

Vaze, J., Post, D. A., Chiew, F. H. S., Perraud, J.-M., Viney, N., and Teng, J.: Climate nonstationarity - Validity of calibrated rainfallrunoff models for use in climate change studies, J. Hydrol., 394, 447-457, doi:10.1016/j.jhydrol.2010.09.018, 2010.

Viney, N. R., Perraud, J., Vaze, J., Chiew, F. H. S., Post, D. A., and Yang, A.: The usefulness of bias constraints in model calibration for regionalisation to ungauged catchments, 18th World IMACS Congress and MODSIM09 International Congress on Modelling and Simulation, Cairns, July, 2009a.

Viney, N. R., Post, D. A., Yang, A., Willis, M., Robinson, K. A., Bennett, J. C., Ling, F. L. N., and Marvanek, S.: Rainfall-runoff modelling for Tasmania, CSIRO Water for a Healthy Country Flagship, Australia, 2009b.

Wilby, R. L. and Harris, I.: A framework for assessing uncertainties in climate change impacts: Low-flow scenarios for the River Thames, UK, Water Resour. Res., 42, W02419, doi:10.1029/2005WR004065, 2006.

Wood, A., Leung, L. R., Sridhar, V., and Lettenmaier, D. P.: Hydrologic implications of dynamical and statistical approaches to downscaling climate outputs, Climatic Change, 62, 189-216, doi:10.1023/B:CLIM.0000013685.99609.9e, 2004.

Yin, J. H.: A consistent poleward shift of the storm tracks in simulations of 21st century climate, Geophys. Res. Lett., 32, L18701, doi:10.1029/2005GL023684, 2005.

Zhang, X., Zwiers, F. W., Hegerl, G. C., Lambert, F. H., Gillett, N. P., Solomon, S., Stott, P. A., and Nozawa, T.: Detection of human influence on twentieth-century precipitation trends, Nature, 448, 461-465, doi:10.1038/nature06025, 2007.

Zou, L., Zhou, T., Li, L., and Zhang, J.: East China summer rainfall variability of 1958-2000: dynamical downscaling with a variable-resolution AGCM, J. Climate, 23, 6394-6408, doi:10.1175/2010JCLI3689.1, 2010. 